\title{
INTEGRATED LEGAL REGIME OF TOUR OPERATOR BANKRUPTCY PREVENTION AS A SUBJECT OF PRIVATE AND PUBLIC LAW REGULATION
}

\author{
Anatoly V. Guryev \\ Volgograd Institute of Management - the Branch of the Russian Academy of National Economy \\ and Public Administration under the President of the Russian Federation, Volgograd, Russian Federation
}

Introduction: state policy in the sphere of tourism is one of the priority directions of development of the Russian economy, which implements the constitutional right of citizens to rest. However, due to have taken place in recent years, interruptions of business and subsequent announcements of its financial insolvency of a number of tour operators thousands of tourists have lost already paid vacation. With respect to the individual tour operators filed a bankruptcy case. The inadmissibility of violation of the rights and legitimate interests of the users of tourist services, taking into account the social character of the latter, is an important factor in the production of state of effective legal measures to prevent negative consequences of improper performance of obligations by persons engaged in entrepreneurial activity in the sphere of tourism. Intention of research - comprehensive analysis of the legal norms regulating organizations of bankruptcy prevention, and development of recommendations on improvement of legal regulation of relations developing on the prevention of the failure of the tourist organization-tour operator to meet the statutory financial requirements, in order to avoid subsequent recognition bankrupt. Methods basis of the thesis applied the general principles of scientific knowledge (comprehensiveness, consistency, objectivity, methodological pluralism), scientific methods of cognition (comparison ascent from the abstract to the concrete, etc.), general logical methods (analysis, synthesis, induction, deduction, generalization, classification, abstraction, etc.), specially-legal methods (formal and legal, comparative legal method of interpretation of the law, dogmatic, and others). Results: formed integrated legal regime of tour operator bankruptcy prevention, which includes the subjects, composition and consistency of risk monitoring loss of solvency tour operator, conditions and methods of prevention of bankruptcy the tour operator without the involvement and the involvement of third-party lenders, as well as the joining as a way to prevent bankruptcy of the tour operator under the agreement other Tourism Organization. Conclusions: fundamental importance is the correct definition of the moment, which means the start of measures to prevent the loss of solvency of the tour operator. This requires continuous monitoring of the financial condition of the tourism organization.

Keywords: bankruptcy prevention, tour operator, integrated legal regime, reorganization, joining, payment calendar, financial soundness indicators, monitoring, creditors.

\section{КОМПЛЕКСНЫЙ ПРАВОВОЙ РЕЖИМ ПРЕДУПРЕЖДЕНИЯ БАНКРОТСТВА ТУРОПЕРАТОРА КАК ПРЕДМЕТ ЧАСТНОГО И ПУБЛИЧНО-ПРАВОВОГО РЕГУЛИРОВАНИЯ}

\author{
Анатолий Владимирович Гурьев \\ Волгоградский институт управления - филиал Российской академии народного хозяйства \\ и государственной службы при Президенте РФ, г. Волгоград, Российская Федерация
}

Введение: государственная политика в сфере туризма является одним из приоритетных направлений развития российской экономики, которое реализует конституционное право гражданина на отдых. 
Однако из-за произошедших в последние годы приостановок предпринимательской деятельности и последующих объявлений о своей финансовой несостоятельности ряда туроператоров тысячи туристов лишились уже оплаченного отдыха. В отношении отдельных туроператоров возбуждены дела о банкротстве. Недопустимость нарушения прав и законных интересов лиц, пользующихся туристскими услугами, с учетом социального характера последних является важным фактором, влияющим на выработку государством эффективных правовых мер предотвращения негативных последствий ненадлежащего исполнения обязательств лицами, осуществляющими предпринимательскую деятельность в сфере туризма. Цель исследования представляет собой комплексный анализ правовых норм, регулирующих предупреждение банкротства организаций, и разработку рекомендаций по совершенствованию правовой регламентации отношений, складывающихся по поводу предупреждения неспособности туристской организации-туроператора удовлетворять законные финансовые требования, во избежание последующего признания банкротом. Методы: применены всеобщие методы научного познания (всесторонность, системность, объективность, методологический плюрализм), общенаучные методы познания (сравнение, восхождение от абстрактного к конкретному и др.), общелогические методы (анализ, синтез, индукция, дедукция, обобщение, классификация, абстрагирование и др.), специально-юридические методы (формально-юридический, сравнительно-правовой, метод толкования норм права, догматический и др.). Результаты: сформирован комплексный правовой режим предупреждения банкротства туроператора, который включает субъектный состав и последовательность мониторинга риска утраты туроператором платежеспособности, условия и способы предупреждения банкротства туроператором без привлечения и с привлечением сторонних кредиторов, а также реорганизацию в форме присоединения как способ предупреждения банкротства туроператора по соглашению с другой туристской организацией. Выводы: принципиально важным является правильное определение момента, означающего старт мероприятий по недопущению утраты туроператором платежеспособности. Для этого необходим непрерывный мониторинг финансового состояния туристской организации.

Ключевые слова: предупреждение банкротства, туроператор, комплексный правовой режим, реорганизация, присоединение, платежный календарь, показатель финансовой состоятельности, мониторинг, кредиторы.

\section{Introduction}

Currently under reform legislation regulating social relations in the sphere of tourist activity. However, the ongoing reforms can not be considered effective in terms of preventing the bankruptcy of tour operator. The aim of this reform is to eliminate and often only mitigate the adverse effects of improper performance of the tour operator with its obligations in relation to the consumer. This fact can be explained by the fact that the bankruptcy warning tourist organizations is currently not subject to a special legal regulation. Practice shows that in recent years, in the absence of an integrated approach to the development of measures to prevent the bankruptcy and restore solvency of tourist organizations, it is impossible to fully ensure the protection of rights and legitimate interests not only of the tourist product consumers, but also other operators creditors [2].

Thus, it is necessary theoretical study and practical application of methods of prevention of bankruptcy of tour operators in order to stabilize their business.

\section{The sequence of risk monitoring loss of tour operator solvency [1]}

According to Par. 2 of Art. 4 of the Federal Law dated 26.10.2002 № 127-FZ «About Insolvency (Bankruptcy)» [9] in determining the existence of signs of bankruptcy organization takes into account the following indicators:

- the amount of monetary obligations, including the amount payable for the goods, works and services rendered, loan size (according to the author, the estimated cash loans) with interest payable by the borrower, the amount of debt that has arisen as a result of unjust enrichment and the amount of debt resulting from damage to property of creditors, with the exception of obligations to citizens, to whom the organization is responsible for causing harm to life or health, the obligation to pay compensation over and above compensation for damage, severance payments and salaries of persons working under a labor contract, the obligation to pay compensation the authors of results of intellectual activity, as well as obligations to the founders (participants) of the debtor arising from such participation; 
- the amount of compulsory payments without regard to the Russian Federation legislation fines (penalties) and other financial sanctions.

On 29 January 2015, in accordance with Par. 2 of Art. 6 of the Federal Law dated 26.10.2002 № 127-FZ «About Insolvency (Bankruptcy)» in order to avoid arbitration court recognition bankrupt the tour operator figures shown together must not exceed 300 thousand rubles [7].

Consequently, the legislator gives the right to the arbitral tribunal to institute the bankruptcy case of the legal entity (in this case the tour operator) in the presence of the following conditions:

1) failure of tour operator debtor monetary obligations (including the obligation to pay mandatory payments to the appropriate budget of public legal education, payments to the funds) within 3 months from the date of occurrence of such an obligation;

2) operators debt under liabilities to one recipient is not less than 300 thousand rubles.

Therefore, in order to prevent occurrence of insolvency and non-excitation of the arbitration court of the bankruptcy case, the tour operator is obliged to continuously carry the risk of loss of solvency monitoring in time to the identified manifestations of insolvency by various means to eliminate.

This obligation tour is due in the first place, the desire to properly perform its contractual obligations rather than to creditors-entrepreneurs and founders of the tour operator, as the consumers of the tourist product (tourist), since the latter are economically weak side, compared with the tour operator, other creditors and, especially, by the state. In addition, it is worth noting the lack of clarity of the legislator approach to the disclosure of the concept of contract sale of the tourist product [6].

To solve this problem, the tour operator is necessary to create a kind of «signal» system - a warning notification system about the potential loss of their solvency, the content of which is the continuous monitoring of signs of insolvency (risk of loss of solvency) the tour operator.

According to the author, based on the essence of entrepreneurial activity of the tour operator, tour operators delay the execution of monetary obligations and mandatory payments for a period exceeding one month is not allowed. Also, according to the author, the amount of 300 thousand rubles indebtedness and above can not be applied to the tour operator, as there are plenty of tours, which cost several times less than the amount of 300 thousand rubles. Therefore, it is possible to formalize the financial viability of the measure the tour operator in the form of a factor as follows:

$$
\mathrm{K} \mathrm{C}_{\mathrm{TO}}=\mathrm{T}_{\text {то }}: \mathrm{O}_{\text {то }} \geq 1 \text {, }
$$

where $\mathrm{T}_{\mathrm{TO}}$ - is the sum of the tour operator to the debtor in the current month; $\mathrm{O}_{\mathrm{TO}}$ - is the amount of monetary obligations and mandatory payments, the period of performance which occurs in the current month; 1 (one) - the size of the target ratio of the sum of the requirements of the tour operator and the amount of monetary obligations and mandatory payments the tour operator for the current calendar month.

Actual $К Ф \mathrm{C}_{\mathrm{TO}} \geq 1$ indicates that the funds received from the contractors is sufficient for the execution of current financial obligations to creditors and compulsory payments, and the financial viability of the stock is sufficient to fulfill the commitments for the next two months.

Actual $\mathrm{K} \mathrm{C}_{\mathrm{TO}}<1$ indicates that the tour operator requires measures to improve the business and improve the financial viability.

The author draws attention to the fact that the calculation of this index is not so much economic as it is due to the legal nature of the attachment factor to insolvency grounds, established by the Federal Law dated 26.10.2002 № 127-FZ «About Insolvency (Bankruptcy)» in view of the explanations which have been given above.

\section{Conditions and ways}

\section{of the tour operator bankruptcy warning without the involvement and assistance of other creditors [4]}

The state regulates social relations for the prevention of bankruptcy the tour operator, not only through their bodies, but also through them by legal entities that are an integral part of the state mechanism [5].

The basic condition for the tour operator bankruptcy prevention is to maintain adequate 
solvency it. The above proposed formula for calculating the indicator of financial solvency tour

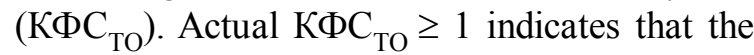
funds received from the contractors is sufficient for the execution of current financial obligations to creditors and for the execution of the current compulsory payments and the financial viability of the stock is sufficient to fulfill the commitments for the next two months.

The main way to maintain a strong solvency tour operator is to increase the weight of the incoming cash as bank accounts and checkout operators. This method is implemented in the framework of activities to raise funds.

Schematically, the author suggested methods and conditions for the tour operator bringing cash presented in Table.

From this Table it is clear that if the tour operator a decision on raising funds from domestic creditors, in cases where $К Ф \mathrm{C}_{\mathrm{TO}}$ accept these values, tour leader can initiate collective bargaining with the employees of the organization. And also speak at the general meeting of the founders (participants) tour with a proposal to increase the authorized capital, the provision of the founders (participants) of financial aid, to conclude with the founders (participants) about the grant of financial assistance agreement (deed of gift or contract gratuitous targeted funding). If the tour operator a decision on raising funds from the vernal creditors in cases where $\mathrm{K} \mathrm{C}_{\mathrm{TO}}$ accept these values, tour operator leader can make with a commercial entity independent guarantee contract.

If the tour operator taken a comprehensive solution of raising funds and of the vernal and from domestic creditors, the head of tour operator or founder (participant), depending on which value takes $К Ф \mathrm{C}_{\mathrm{TO}}$ may at a general meeting of the founders (participants) to offer a comprehensive plan to restore the solvency of tour operator. This plan should contain a list of measures to restore the financial viability of the organization, as well as the sequence of these events.

At the same time in order to prevent the recognition of these activities void transactions; they must comply with the applicable civil law, including special legislation on specific types of legal entities, and insolvency law.

\section{Joining as a way to prevent bankruptcy of the tour operator, in agreement with other Tourism Organization [3]}

There may be a situation in which the ways to restore the solvency of tour operator, which are considered in the preceding paragraphs, can not have a positive impact on the financial viability

Methods and conditions for raising funds for the prevention of bankruptcy of the tour operator

\begin{tabular}{|c|c|c|c|}
\hline \multicolumn{2}{|c|}{ Methods of raising funds } & Terms of raising funds & Subjects and foundation fundraising \\
\hline \multirow[t]{3}{*}{$\begin{array}{l}\text { Raising funds from } \\
\text { domestic creditors }\end{array}$} & $\begin{array}{l}\text { The increase in the } \\
\text { authorized capital of the } \\
\text { legal entity }\end{array}$ & $\begin{array}{l}\text { at } \mathrm{K} \Phi \mathrm{C}_{\mathrm{TO}} \geq 0,66, \\
\text { but less than } 1\end{array}$ & $\begin{array}{l}\text { The founders (participants); } \\
\text { the decision of the general meeting }\end{array}$ \\
\hline & $\begin{array}{l}\text { Provision by the founders } \\
\text { (participants) of financial } \\
\text { aid to a legal entity }\end{array}$ & $\begin{array}{c}\text { 1) } 0,66 \leq \mathrm{K} \Phi \mathrm{C}_{\mathrm{TO}}<1 ; \\
\text { 2) } 0,33 \leq \mathrm{K} \Phi \mathrm{C}_{\mathrm{TO}}<0,66\end{array}$ & $\begin{array}{l}\text { The founders (participants); } \\
\text { the contract of donation (if the } \\
\text { participant - natural person); } \\
\text { contract gratuitous targeted } \\
\text { funding }\end{array}$ \\
\hline & Providing interest-free loan & 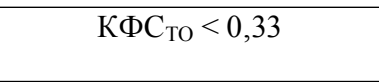 & $\begin{array}{l}\text { The founders (participants); } \\
\text { contract-free loan }\end{array}$ \\
\hline \multirow[t]{2}{*}{$\begin{array}{l}\text { Raising funds from } \\
\text { domestic creditors }\end{array}$} & $\begin{array}{l}\text { Collective bargaining in } \\
\text { preparation of collective } \\
\text { agreements and collective } \\
\text { bargaining projects }\end{array}$ & $\begin{array}{l}\text { 1) unsatisfactory results of } \\
\text { other ways of raising funds; } \\
\text { 2) } 0,66 \leq \mathrm{K} \mathrm{C}_{\mathrm{TO}}<1 \text {; } \\
\text { 3) } 0,33 \leq \mathrm{K} \mathrm{C}_{\mathrm{TO}}<0,66 \\
\text { 4) } \mathrm{K} \Phi \mathrm{C}_{\mathrm{TO}}<0,33\end{array}$ & $\begin{array}{l}\text { Tour operator's employees; } \\
\text { collective agreement }\end{array}$ \\
\hline & $\begin{array}{l}\text { The participation of workers } \\
\text { and their representatives in } \\
\text { the management of the } \\
\text { organization }\end{array}$ & $\begin{array}{c}\text { 1) } \mathrm{K} \Phi \mathrm{C}_{\mathrm{TO}} \geq 1 \\
\text { 2) } 0,66 \leq \mathrm{K} \mathrm{C}_{\mathrm{TO}}<1 \\
\text { 3) } 0,33 \leq{\mathrm{K} \Phi \mathrm{C}_{\mathrm{TO}}<0,66} \text { 4) } \mathrm{К} \Phi \mathrm{C}_{\mathrm{TO}}<0,33\end{array}$ & $\begin{array}{l}\text { Tour operator's employees; } \\
\text { local normative acts of the } \\
\text { employer (tour operator) }\end{array}$ \\
\hline $\begin{array}{l}\text { Raising funds from } \\
\text { external creditors }\end{array}$ & $\begin{array}{l}\text { Conclusion independent } \\
\text { guarantee contract }\end{array}$ & $\begin{array}{l}\text { 1) } 0,66 \leq{\mathrm{K} \Phi \mathrm{C}_{\mathrm{TO}}<1} \text { 2) } 0,33 \leq \mathrm{K} \mathrm{C}_{\mathrm{TO}}<0,66 \\
\text { 3) } \mathrm{K} \Phi \mathrm{C}_{\mathrm{TO}}<0,33\end{array}$ & $\begin{array}{l}\text { The commercial legal entity; } \\
\text { the contract guarantees an } \\
\text { independent }\end{array}$ \\
\hline
\end{tabular}


and the continuation of normal operations tour operator.

In this case, in order to prevent its bankruptcy, the tour operator can initiate the process of reorganization.

From the point of view of ways of preventing the bankruptcy of tour operator, consider further legal regulation of this form of reorganization of the legal entity as the accession. In this case, it should be clarified that in the framework of this thesis other forms of reorganization will not be considered in view of the relatedness of the author with the requirements on the amount of the research. The main advantage of joining to other forms of restructuring in terms of the prevention of bankruptcy, according to the author, is a transfer of rights and obligations of financially insolvent tour operator to tour operator, having not only sufficient economic assets, but also to earn goodwill. It is the lack of goodwill from the newly established legal entity through the merger and explains the interest of the author to consider the merger as a way to prevent the bankruptcy of tour operators.

With the present expansion of the integration process, as one of the consequences of economic globalization, integration of businesses and the expansion of areas of business merger is one of the main companies of reforming methods.

In addition to the above is necessary to provide the procedure of reorganization measures in the form of a merger. In particular, according to the author, the said procedure shall consist of the following stages.

1. Preparatory stage. At this stage, the tour operator insolvency sends the SRO, of which he is a notice of intention to begin the process of reorganization in the form of a merger. In this notice the tour operator must provide information about the causes of financial insolvency on the measures taken to restore the solvency of the amount of liabilities to counterparties, as well as the cost of the existing tour operator property (including cash and the right to claim). The notification of insolvent tour operator has the right to apply agreed to join the tour operator's readiness to begin the reorganization procedure in the form of a merger. The said agreement is supported by documents confirming the stable financial condition affiliating tour. In turn, the SRO considers these documents to determine the presence of legal grounds for merger, checks on conformity to the documents concerning the financial condition of operators potentially affiliating is reasoned opinion. The report should contain an opinion about the expediency or inexpediency of the reorganization. These findings together with all the documents sent to the Rosturizm.

2. Organizational stage. During this phase Rosturizm based on the conclusion obtained from the SRO insolvent tour operator, tour operator identify potential affiliating. Determination of the tour operator is carried out in the absence of consent in the resulting documents solvency Tourism Organization, or, if deemed inappropriate Rosturizm nominee agrees to tour operator. This Rosturizm gives a reasoned explanation for its refusal this tour operator. For this Rosturizm assesses the state of the market in the tourism sector, making requests at all the SRO tour operators to provide information about the presence or absence of tour operators with a stable financial condition. Priority should be given to tour operators who carry out their activities in the same region of the Russian Federation, as tour operator insolvency. Next Rosturizm sends a request to the tour operator about the affiliating potentially willingness or unwillingness to begin the process of restructuring the tour operator. To encourage wealthy summer attach to itself insolvent tour operators should be provided in tax legislation granting consolidating the tour operator "tax holidays", i.e. the release of the tour operator on the basis of regulation of tax (including income tax) from 1 to 5 years (depending on of the volume of the affiliated tour operator commitments). After receiving a positive response, Rosturizm directs participants to the reorganization of the prescription of the need to organize a general meeting of the founders (shareholders) of each of the participants in the reorganization, joint general meeting of the founders (shareholders), as well as the timing of their implementation.

3. The pre-registration phase. At this stage, based on the requirements the Federal Tourism Agency, carried out the general meeting of the founders (or shareholders) of the participants in the reorganization, as well as joint general meeting, which resulted in a decision to hold the merger, is the merger agreement, drawn up the transfer act, if necessary made the appropriate changes to the 
charter of the affiliating tour. In the contract, as the cause of the reorganization, the loss of solvency of connected tour operators should be specified. Note the reasons for restructuring is necessary in order to obtain a possible tour operator join a bank loan, for which the author mentioned above.

4. State registration of the merger. During this phase, carried out actions aimed at the legalization of accession. The legislation established that state registration is carried out in a period of not more than five working days from the date of submission of documents to the registering authority, unless otherwise provided by federal law [5]. It seems that for the state registration of the merger, which is due to the financial insolvency of tour operator, you need to install special reduced terms. According to the author, the term of such registration shall be five calendar days from the date of submission of documents to the registering authority. The establishment of such a reduction of the term will more quickly to solve the problem to meet the claims of creditors of the adjoint tour operator.

\section{Results}

The author based on the analysis of various situations of business tour operator introduced measure the financial viability of tour operator in

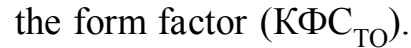

This indicator of financial solvency tour operator can be represented by the formula consisting of actual data, namely the ratio of claims to liabilities for the current calendar month. The result obtained by dividing the sum of the amount of claims liabilities for the current calendar month, according to the results of the author's argument, must be at least 1 (one).

To maintain the ratio (index) the financial viability of tour operator - $К Ф \mathrm{C}_{\mathrm{TO}}$ - at the level of not less than 1 requires a set of measures to attract funds from both internal (shareholders and employees of tour operator) as well as from external creditors.

Data on financial soundness indicators tour operator with supporting documents at least once every three months should be sent to the SRO tour operator with subsequent publication. In the course of the research it was found that, in contrast to the credit institutions, city-forming organizations, agricultural organizations and other specific types of business entities, the main sources of causes of tour operators solvency and the onset of the signs of bankruptcy, in addition to objective reasons is a lack of practical developments and regulatory implementation methodology for the prevention of bankruptcy of tour operators. The need for these developments due to the fact that the objectives of the institution of bankruptcy is to provide a balance of rights and legitimate interests of the persons participating in the bankruptcy case, the fair and balanced satisfaction of all creditors. However, the current bankruptcy law is not conducive to achieving this goal.

Accordingly, based on the results of this research the author has established the recommendations to improve the existing regulatory framework.

In addition to the scientific conclusions and recommendations to improve the existing regulatory framework, spent research has allowed the author to develop some practical recommendations for the prevention of bankruptcy in the implementation of the tour operator business activities, in particular:

1) the tour operator must create a «signaling» system - a system of preventive alert about the potential loss of their solvency, the content of which is a daily comparison of all the obligations and requirements of tour operator in terms of a calendar month, in accordance with existing agreements and public responsibilities;

2) for operational monitoring of solvency risk of loss of the tour operator you must be of payments calendar, in which shall be entered particulars of the maximum period ( 3 months) the execution of a monetary obligation as a private law and public law;

3) we can calculate the average of the financial viability of tour operator (the sum of the coefficients for the entire monitoring period, divided by the number of months of the monitoring period with long-term and daily monitoring of the risk of loss of the tour operator's solvency (60 months or more)). The results of this monitoring should be part of the executive body of the report to be submitted for approval by senior tour operator management body (general meeting of shareholders). 


\section{Conclusions}

Thus, a comprehensive scientific study on the prevention of bankruptcy tourism organizations important in terms of increasing the efficiency of public authorities in general and the legal regulation of these social relations, in particular. Scientific developments, including this thesis, will be in demand during the period of formation and development of system of the relevant rules and measures in the business law of Russia.

\section{REFERENCES}

1. Guryev A.V. Poryadok monitoringa riska utraty turoperatorom platezhesposobnosti [The Procedure of Monitoring Risk of Tour Operator's Solvency Loss]. Vestnik Volgogradskogo gosudarstvennogo universiteta. Seriya 5, Yurisprudentsiya [Science Journal of Volgograd State University. Jurisprudence], 2016, no. 2 (31), pp. 119-124.

2. Guryev A.V. Pravovye aspekty preduprezhdeniya bankrotstva turoperatora [Legal Aspects of Tour Operator's Bankruptsy Prevention]. Moscow, Yustitsinform Publ., 2017. 252 p.

3. Guryev A.V. Reorganizatsiya $v$ forme prisoedineniya kak sposob preduprezhdeniya bankrotstva turoperatora po soglasheniyu s drugoy turistskoy organizatsiey [Reorganization in the Form of Conjunction as a Way to Prevent Tour Operator's Bankruptsy upon the Agreement with Another Tourism Company]. Vestnik SPbGU. Seriya 14, Pravo, 2016, no. 3, pp. 65-73.

4. Guryev A.V. Usloviya i sposoby preduprezhdeniya turoperatorom bankrotstva bez privlecheniya storonnikh kreditorov [Conditions and Ways of Tour Operator's Bankruptsy Prevention without Involving Creditors]. Pravo i ekonomika, 2016, no. 3,pp. 31-35.
5. Guryev A.V. Uchastie publichnykh i chastnykh organizatsiy - regulyatorov $\mathrm{v}$ meropriyatiyakh preduprezhdeniya bankrotstva turoperatora [Participation of Public and Profit Organizations Regulators of the Activities of Tour Operator's Bankruptsy Prevention]. Vestnik Volgogradskogo gosudarstvennogo universiteta. Seriya 5, Yurisprudentsiya [Science Journal of Volgograd State University. Jurisprudence], 2015, no. 3 (28), pp. 109-114.

6. Kazachenok O.P. Sootnoshenie dogovora okazaniya turisticheskikh uslug i dogovora realizatsii turisticheskogo produkta [Correlation of Agreement of Tourism Services Rendering and Agreement of Tourism Product Sale]. Novyy universitet. Seriya "Ekonomika i pravo”, 2014, no. 05-06 (39-40), pp. 36-39.

7. Federalnyy zakon Rossiyskoy Federatsii «O vnesenii izmeneniy v Federalnyy zakon "O nesostoyatelnosti (bankrotstve)" i otdelnye zakonodatelnye akty Rossiyskoy Federatsii v chasti regulirovaniya reabilitatsionnykh protsedur, primenyaemykh $\mathrm{v}$ otnoshenii grazhdanina-dolzhnika» ot 29.12.2014 № 476-FZ [Federal Law of the Russian Federation "On Amending the Federal Law 'On Insolvency (Bankruptsy)' and Certain Legal Acts of the Russian Federation with Regard to Regulating Reabiliation Procedures Appled in Relation to a Debtor" of December 29, 2014 no. 476-FL]. Rossiyskaya gazeta, 2014, Dec. 31, no. 299.

8. Federalnyy zakon «O gosudarstvennoy registratsii yuridicheskikh lits i individualnykh predprinimateley» ot 08.08. 2001 № 129-FZ [Federal Law "On State Registration of Juridical and Individual Businessmen" of August 8, 2001 no. 129-FL]. Sobranie zakonodatelstva RF,2001, Aug. 13, no. 33, part I, art. 3431.

9. Federalnyy zakon $« \mathrm{O}$ nesostoyatelnosti (bankrotstve)» ot 26.10.2002 № 127-FZ [Federal Law "On Insolvency (Bankruptsy)" of October 26, 2002 no. 127-FL]. Sobranie zakonodatelstva RF, 2002, Oct. 28 , no. 43 , art. 4190.

\section{Information About the Author}

Anatoly V. Guryev, Lector, the Department of Civil-Lawful Disciplines, Volgograd Institute of Management - the Branch of the Russian Academy of National Economy and Public Administration under the President of the Russian Federation, Gagarina St., 8, 400131 Volgograd, Russian Federation, tolya_gurev@mail.ru.

\section{Информация об авторе}

Анатолий Владимирович Гурьев, преподаватель кафедры гражданско-правовых дисциплин, Волгоградский институт управления - филиал Российской академии народного хозяйства и государственной службы при Президенте РФ, ул. Гагарина, 8, 400131 г. Волгоград, Российская Федерация, tolya_gurev@mail.ru. 